\title{
THE UNDERSTANDING OF SECURITY IN THE POSTMODERN SOCIETY
}

\author{
Svilen Stefanov ${ }^{1}$, Venelin Terziev ${ }^{2}$, Vanya Banabakova ${ }^{3}$ \\ ${ }^{1}$ Prof, Ph.D., National Military University, Veliko Tarnovo, Bulgaria, sestefanov@abv.bg \\ ${ }^{2}$ Corresponding Member of the Russian Academy of Natural History, Moscow, Russia, Prof. \\ D.Sc.(Ec.), D.Sc. (National Security), D.Sc. (Social Activities), Ph.D., National Military University, \\ Veliko Tarnovo, Bulgaria; University of Rousse, Rousse, Bulgaria, terziev@skmat.com \\ ${ }^{3}$ Prof. Ph.D., National Military University, Veliko Tarnovo, Bulgaria, email: v.banabakova@abv.bg
}

\begin{abstract}
The rapid development of science and technology has led to the emergence of a crisis in society. Science "pushes" religion, but does not offer a new moral code in its place. The definitions of "security" are almost as many and as controversial as postmodernism. For the purposes of this study, however, it will be sufficient to define security as "the functional state of a system that provides for the neutralization and counteraction of external and internal factors affecting or potentially damaging the system." This scientific article presents a study, which seeks to answer the question why the paradigm "security" is so important in the postmodern society, what are the roots of its influence and meaning, and to seek conclusions and guidelines for its increase. The main features of the postmodern society, some prerequisites and their implications, as well as their impact on the security of all its levels are examined. The subject of the study is the postmodern society with its specific features, and the subject - the security as an indissoluble element of the social relations in the contemporary world.
\end{abstract}

Keywords: security postmodern society, globalization.

\section{INTRODUCTION}

It is accepted that modern times begin with the bourgeois revolutions in France and England (16th century) and finish after the end of the Second World War (the middle of the 20th century). The main processes that take place during these times appear also to be its characteristics that radically distinguish it from the previous ones. More significant of them are as follows:

The Age of discovery that extremely widens the views of the man of the time, and beside that it confirms some major thesis of the then science, namely the idea that Earth is not flat and that it is not the centre of the Universe, etc.

The economical relationships and interests coming to the fore, which, in the course of the times remove completely the previous ones, built on the grounds of aristocracy.

Science development that leads to improvement and elaboration of new production technologies. 
IJASOS- International E-Journal of Advances in Social Sciences, Vol. IV, Issue 12, December 2018

The gradual reduction of the influence of religions and particularly of Christianity upon social conscience.

The listed characteristics are interrelated through positive reverse relation - science development creates new technologies that, in their turn, change the economic environment and the social relations and remove religious beliefs. On the other hand, the better and more precise technologies as well as the social trust in science establish environment for its faster development. This also leads to extremes like, for example, the so called Laplace's demon according to which if we knew the laws of universe and its initial status, we could predict its behaviour for a unspecified period of time, or its status at any moment.

The rapid progress of science and technologies leads to the emergence of crisis in society. Science „pushes aside" religion but does not suggest a new moral code in exchange. Even the contrary, the wide application of new technologies in the times of both world wars and this mainly for making weapons of mass destruction shows that scientific results application without moral restraints leads to creepy consequences. The lack of "goals" and "reference points" in the society's moral grounds of societal consciousness creates preconditions for loss of the system of values in practically several generations. Unfortunately, this process has not finished even today. Probably just this is the reason for the restoration of radical Islamism. Number of movements and philosophies arise in the years after the Second World War, which try to fill this vacuum in social relations. Typical examples for that are the hippie movement in the USA, "The Angry Young Men" in England and many more. Anyway they did not succeed in establishing clear and acceptable social platform, because of which they disappear and leave only blurred trace.

All this is important because it creates the preconditions modern society builds up on.

The term "postmodernism” means what comes after modernism. As some researchers say, the affix „post” is very convenient because it shows that modernism evolves directly from modernism and the transition from one to the other has evolutionary rather than revolutionary nature. The term "postmodernism" (2017a) is used for the first time yet in 1917 in the works of Rudolf Pannwitz, German writer and philosopher-essayist. Later the term is used by number of autors with various meanings, but mainly to present modern experimental streams in art, which do not follow the ideas of "modernism”specially in abstract art. Actually, most often what is understood behind the term „postmodernism” in art is returning to realism and creation of works (artistic, literature, etc.) accessible for understanding by the wide masses or, in other words - denial of modernism. The term gains real popularity with the publication of the book "The Language of Post-Modern Architecture" by the American architect Charles Jencks in 1977. Later the meaning of the term „postmodernism” extends and range over philosophy, sociology and practically all spheres of modern science and art. This happens with the occurrence of a stream in the French philosophy (Althusser, Derrida, Lyotard, etc.). Actually, at the moment there are quite a number of definitions of „postmodernism”, used and founded by various schools in science and art, and great part of them are completely mutually exclusive. Here are some examples:

Jürgen Habermas, Daniel Bell and Zygmunt Bauman define postmodernism as result of politics and ideology of neoconservatism, characterized by aesthetic eclecticism, turning objects for consumption into fetishes and other specific features of postinductrial society;

Umberto Eco interprets postmodernism in a broad sense, as mechanism for change of one cultural period with another;

Hassan, Welch, Lyotard consider that postmodernism is a common cultural denominator of the second half of the 20th century, unique period, where the world is reviewed as chaos;

According to Letten and Suleiman postmodernism does not exist, it could be reviewed as giving a new meaning to the cultural postulates of modernism, but the independent postmodern reaction is a myth;

Küng and Tarnas - postmodernism is a period that comes to change the European „New Age”. The latter is characterized by infinite trust in the power of mind and progress. The crash of the value system has happened during the First World War. As a result, the Euro-centric paradigm is exchanged for a global polycentrism, and the infinite trust in mind gives up its place to the „interpreting thinking”.

Naturally, there are number of critics towards the thesis of postmodern society. Most of them are directed to the statement that postmodernism does not exist and this is rather late modernism (Chomsky, Dennett, Solzhenitsyn, etc.)

It is obvious that modern world is not the same as it was during the first half of the 20the century. Public, social and economic relations undergo changes, transform in new and different things, which most of the time are unknown from the history of humankind. This shows we really are in a new period. Whether we'd call it postmodernism or another way is not an essential issue in this case. It is more important to know its 
characteristics and to be prepared for the coming changes. All authors, who develop the thesis about postmodernism and the society in this period, unite around one idea. The chaos in public, social, political and economic relations, the crash of the old value systems and the lack of new ones to exchange them are features showing that actually this is a transitional period, transitional process while the society (as a system) transfers form one status to another. Unfortunately, the new status and the new relations are not outlined yet and practically cannot be defined and clearly pointed. Historical references point that these transitional periods are characterized by long continuance and very often by impetuous social events, wars and bloodshed.

Logically, as extension of the reasoning above, the term „security” comes. And here, almost all authors examining postmodernism are unanimous about security being one of the leading paradigms of modern society. Its significance grows exponentially I would say, during the last years and this reviewed mainly from practical point of view rather than in theoretical respect.

The definitions of the term "security" are almost as many and controversial as the ones of postmodernism. But it would be sufficient, for the goals of the present study, to define security as "given system's functional status that ensures its neutralization and counteraction to external and internal factors, which influence or able to impose destructive influence upon the system" (2017b).

The goal of the present study is to look for an answer to the question why the paradigm "security" is so important in the postmodern society, what are the roots of its influence and significance and respectively, to look for conclusions and directions for its enhancement. The main characteristics of the postmodern society, some preconditions and their consequences as well as their impact upon security at all its levels would be reviewed.

The study's subject is the postmodern society with its specific features and its object - the security as an inseverable element of social relations in the modern world.

\section{POSTMODERN SOCIETY}

The defining of the term „postmodern society” is quite heterogeneous and controversial according various researchers. This is the reason not to focus on particular definitions but to focus our attention upon its characteristics. Similar to the short description of the modern society, actually, the basic processes going during the relevant period appear to be also its main characteristics. On this grounds the main processes that define the difference of postmodernism in regard to the previous periods could be systematized in the following groups: globalization; loss of legitimacy of „the state”; technological revolutions; the crash of big ideologies; the end of the individual "role" models; the end or the transformation of "communities"; the new generations $(Y, Z, \alpha)$.

It is possible to derive number of other processes and characteristics of postmodern society but the author considers that the listed above are the more significant and most of the rest could be reviewed as subsystems or elements. I'd point as an example "the death of God”. Actually, this could be reviewed as element of the crash of the big ideologies.

As it was also mentioned above, the listed characteristics are interrelated with a whole system of straight and reverse relations, which makes the understanding of postmodern society extremely complicated and often evokes researchers' feeling that all in the modern world is chaotic, deprived of any logic and order.

The main part of the characteristics of postmodern society mentioned above, are taken from N. Slatiniski (Slatinski, 2014a), Z. Bauman (2017c) and other sources, and this compilation as well as the adding of the last element are suggestions of the author of the present study. There is no pretension for comprehensiveness and full inclusion of all characteristics of postmodern society, still more; practically each researcher elaborates his own system of characteristics and criteria for their study and the section between these multitudes is almost empty.

Let us review briefly each of the listed characteristics of postmodern society and some major relations between them.

\section{GLOBALIZATION}

"Globalization is the process of the enhancement of economic, social, technical, political and cultural interrelations and relationships between the individual states, organizations and people. It is connected with global distribution and mutual penetration of ideas, capitals, technologies and elements of culture.

Although contacts between comparatively remote regions exist yet in Antiquity, they acquire global scope hardly after the Age of Discovery in the 14th -16 th century. The rapid development of transport and 
communication equipment in the 20th century leads to rapid intensification of the process of globalization by the expansion of international trade and transfer of capitals and the establishment of the first political institutions of global scale.

Globalization is a process with controversial effect. There are various points of view and positions regarding the benefits and the damages of it, which, in many cases, are influenced by more general ideological views. While globalization supporters review it as factor for economic progress on a world scale, its opponents consider it is cause for economic and ecologic damages" (2017d).

As far as the present study is focused on security, we will focus our attention on this process's negative effects. As Zygmunt Bauman states in an interview for BBC - the biggest trouble is that globalization we are dealing with today is of strictly negative nature. It is grounded on ruining barriers, allowing the globalization of capital, the commodities movement, the information, crimes and terrorism, but not political and legal institutions, which grounds is national independence. The means available now for protecting law and citizens from violation, are obviously insufficient for gaining command of the global forces, which in essence are over-territorial. The events of September 11th and the bomb attacks in Madrid and London showed that these means are, roughly said, useless (2017c). This could briefly be explained the following way - national state, no matter how big and powerful is, does not have power and means to resist global processes that seize the whole world, and global means for fighting the process's negative effects do not exist yet. Actually, the latter is the connection between this process and the state's loss of legitimacy.

The freedom of capitals moving allows moving productions in zones in the world, where economic conditions are more favourable for the relevant companies. This, in its turn, sharply increases the risk of unemployment and long-term lack of employment of people. This process supports also the processes of crime distribution, which, as always, is extremely flexible and able of taking advantage of even the smallest lapses in the security systems.

The freedom of information dissemination, beside all positive effects, allows easy communication of criminal and terrorist groups all over the world. More, the inability for the ruling people to manipulate the information flows contributes to the loss of effectiveness of ideological actions and treatments. However, just the opposite process is observed in the recent years - namely substitution of information, creation of fake news that could direct whole world's public opinion in certain directions for achieving the wanted results. Yet, this process difficultly affects intelligent and critical people, who tend to check information sources and to review situations from all sides. One more aspect of information's global dissemination is the terrorism. Well-known truth is that the power of terrorist acts does not come from the number of victims, sufferers and damages but from swamping the world with information about them and spreading the feeling of fear among the people in the affected and threatened states.

\section{LOSS OF LEGITIMACY OF "THE STATE"}

According to (2017e) legitimacy is a concept for the grounds of the political regime and its representatives that make citizens accept their actions and orders as lawful and true. Legitimacy does not ensue from the official laws and acts, but from the public approval and acceptability, which state governance raises in the governed ones. It is result of not regulated norms and values that are subject to the consent and the approval of most of the citizens.

As it was mention in the previous item, one of the main reasons for the loss of legitimacy of authority is the inability of national state to fight the global processes and threats. The events from the last years, mainly the activity of terrorism worldwide, showed that even a union of several states (the European Union) does not have enough powers to fight these threats.

However, this is not the most important element of the studied process. In (2017c) Bauman says ,instead of doing their duties for protecting the citizens against the insecurity and the resulting fear, governments call to higher flexibility on the labour market and all other spheres regulated by the market forces. And this means more insecurity. The thing they are calling us to is not reduction but increase of risk. One of the consequences of the state withdrawing is legitimacy crisis of state authority. This authority required subjection, discipline and respect for the law, promising the citizens security and just life. But these promises have been neglected one after the other, including free education, basic medical aid, pension insuring and the basic aid for the unemployed. The state is with tied hands; it itself is left in the hands of market powers. If it dares to oppose the market forces, the capital would flow to a place, where it could grow easily and comfortably. Then the nation would run into the scourge of unemployment and poverty". Coming from the definition presented in the beginning of the present item, the described state's behaviour evokes the dissatisfaction of its citizens, and from there loss of legitimacy based on the public approval. 


\section{TECHNOLOGICAL REVOLUTIONS}

According to (2017f) the term "revolution” is defined as radical, deep, fundamental, quality change in the development of the society, nature or knowledge, related to abrupt disconnection of the relations with the previous status of the relevant object. It is not by chance that the name of this item is in plural.

Historically, technological revolutions begin yet in the end of the 19th and the beginning of the 20th century with the progress of the steam machine. According to us the significance of that invention has two very important aspects:

Humankind, for the first time in its history, begins to use source of energy, which is practically besides natural forces;

The progress of the steam machine creates a new scientific field - theory of automatic management, which later turns into base for the development of technical systems and particularly computers.

From this moment on inventions and technological developments start almost one right after the other, which changes considerably not only scientific and technological world but also economic processes and then social relations. As Z. Bauman says in (Bauman, 2003a) "the novelty of our times is in the fact that the periods between compressed and accelerated changes called „revolutions” are not periods of routine any more. The changes themselves are not short periods, separated by long eras of unstable way of life, which makes long-term planning, prognosis and building of "life projects" possible any more. Today we live in a status of permanent revolution. Revolution became form of life of modern society".

Why technological revolutions are so important that they are brought out as one of the major characteristics of postmodern society? First, they created the environment (the ether), where the process of globalization is possible, through the progress of transport and communications. Not less important is the labour productivity increase, which, in its turn, allowed the world gradually to pass to the so called "postindustrial society", although this process is in the bud to this moment and the states that comply with the definition for postindustrial have rather moved their production capacities to third countries. Next, the technological novelties reaching each separate individual created environment for change of people's way of thinking, which we'd study in details in the section about the new generations.

It may summarized be said that technologies penetrated impetuously in all fields of life of the independent individual as well as the one of the society in general. Public and individual consciousness is definitely unprepared for these processes and this causes number of conflicts in moral, educational and purely worldly aspect.

\subsection{The Crash of Big Ideologies}

In (2017c) N. Slatinski emphasizes that in modern society "the state is Ideology but something more, it was society of ideologies”. He uses the term "meta-narratives”, which means big stories, big scenarios, big explanatory diagrams. Again there, they are systematized as follows: ideology (Marxism, Liberalism, Fascism, Anarchism, etc.); religion (Christianity, Islam, Buddhism, etc.); history; science; art; democracy; security; freedom and even Society.

The French philosopher and researcher of postmodernism Lyotard says "If we simplify things to the utmost, we may accept that "postmodern” is mistrust in the meta-narratives” (Liotar, 1996a). Again in (2017c) „According to that thesis postmodernism is mistrust for, disappointment of and critics, crisis and erosion of meta-narratives". The main reason for these processes is the crash of the big ideologies of the 20th century (Fascism, Communism, etc.). Even Democracy more and more often is subject to critics and causes disappointment in individual persons as well as in bigger social groups. This, in its turn, leads to attempts for restoration of old laws and order in some countries in the world.

Big stories are removed by small ones and the latter „do not pretend for universality, truth, rationality, security and are always situational, temporary, spontaneous, cover local events, not large-scale global concepts" (2017c).

One of the consequences of these processes as well as of the communities' transformation, which would be studied further on, is the loss of representativeness of the political objects in society. Parties' role has always been to represent and defend the interests of a particular public stratum. The lack of ideological grounds as well as the merging of strata deprived these objects of their core and tore the connections of political elite with ordinary people, their main problems and worries. Parties and political objects coming to life in the recent years are very often named „people's”, i.e. representing the interest of almost whole nation, or bear names that are not engaged with certain strata and elements of society (GERB, DPS, etc.). Also typical is 
the mixing of left and right ideas in the political platforms of nowadays parties, which clearly shows the lack of purposefulness and public representativeness of these objects. Thus, nowadays elections turn from democratic process directed towards the minds and hearts of people into competition of media manifestations, populist slogans and unfeasible promises.

\subsection{The End of Individual "Role" Models}

„Role” models are typical, above all, for the pre-modern society. Actually, by the term „role model” we will understand the role and place of the separate individual in the society.

Not so long ago, a person's role in society used to be defined not by his capabilities and potential but by the place and environment, he was born in. The farmer's son used to become farmer, blacksmith's son blacksmith, bar keeper's son - bar keeper. This predetermination was considered normal status quo. Actually, the role change was not completely impossible, but the social necessary to be paid for such a change was excessively high and unachievable for the most of the people. The situation with women was slightly different, but generally, social-role model was in power for them, too. Farmer's daughter used to marry a farmer, etc. The role acquired by birth used to accompany the person through his whole life and used to pass to his children.

The modern society's role in this model is that number of new professions emerged during this period (miners, industrial workers, technicians, etc.), which gave chance for many people to try to escape from the acquired by birth roles. However, that does not destroy the model as a whole. The worker's son didn't have chance to become engineer because of the very expensive education and number of other factors. The model continued functioning at full, there was only slight change in roles.

Economic crises as phenomenon of industrial society, played special role in the studied model, by actually, putting most of the people in lower social strata and only single ones succeeded on the grounds of speculation or luck to earn and to raise their status. Typical example for that is the Great depression in the USA in the 30s of the 20th century.

This model is completely destroyed in postmodern society. The main reason for that is the reduction of the value of education and its practical accessibility for everyone who wishes to study. This way each one gets the freedom to choose his role in society depending on his capabilities and potential. Actually, the change of social role has its price but it is considerably lower and accessible for many people, especially in the developed world. The more important is that no one feels bound to his place in the society and could change it at any moment paying relevantly the necessary social price. Actually, this is one of the positive characteristics of postmodernism as far as it gives people the freedom to find the role that suits them best and makes them happy.

An interesting phenomenon in this direction is the so-called „American dream". On one hand, it turns into symbol of consumer society, but on the other is a stimulus for many people to try to find their place in society, to look for new ideas and possibilities for realization.

As a summary, it can be said that the key word in the process of destroying the role model is "Freedom".

\subsection{The End or the Transformation of "Communities"}

According to Zygmunt Bauman (Bauman, 2003b) disintegration of communities is characteristic of postmodern society. Actually, he alludes to, as he calls them „warm communities”, where a person feels secure, protected, understood and mostly at his place in the world. These communities are typical for the pre-modern world and are very close to the definition for "commune" in their essence. Actually, these communities appear to be miniature model of society - self-satisfying their basic needs and having all basic roles for ensuring it. Here the connection between role model disintegration and the disappearing of this type of communities is obvious. Actually, this process begins yet in the modern world. The appearing of new roles and the labour force migration from agriculture to industry destroys "warm communities" disturbing the balance of roles inside them and exhausting their young blood.

The ideology of communism tries to exchange that model for the so-called class model, but the social experiment "socialism" showed later on that the levelling and the artificial grouping of people according some features is not a successful social system. As George Orwell says, „all animals are equal but some are more equal than the others".

Actually Bauman studies also the artificially established communities - „the ghetto community “ and defines their basic differences regarding the „warm” ones.

Postmodern society is not deprived of communities. Particularly in the recent years, the development of 
technologies and especially Internet allowed people's communication from any point in the world. However, the new communities differ significantly from those of the pre-modern society. Actually, I think that the word "societies" could be used as basic principle for forming these; people's interests are of new type. The other feature is that in most of the cases the communication inside them is virtual, i.e. is conducted with the help of technical means. However, this does not prevent the participants from feeling understood and being at their place and to some extent even protected. Typical examples for such communities or societies are the forums. There are several big forums in Bulgaria having numerous members, which, beside the virtual communicating, conduct active social and charity activity. They are ready to help their members as well as everyone else, who needs. Such forums are „BGMamma”, „Offroad”, etc. The MMO (mass multiplayer online) computer games that gained great popularity in the last 10 years have similar effect. The community that forms in them is often international. It is not a surprise at all to see in such a game an American and a Russian fighting shoulder to shoulder for a common cause. This type of games does not limit their activity to only entertainment for people but participate actively in scientific and social projects (Eve online). Some create parallel worlds with completely functioning economic system and operate with real monetary units (Entropia, Second Life). It is already real the possibility for people to make their living through work in virtual game worlds.

The so-called social media (Facebook, $\mathrm{G}_{+}$, Twitter, etc.) are a comparatively new phenomenon. They create „friendships” between people and allow them to share news, opinions, gossips, but also knowledge.

Generally, virtual communication and communities are new fields that are to be subject of serious studies and analysis.

\subsection{The New Generations (Y, Z, A)}

In (McCrindle, 2009a) the Australian sociologist Mark McCrindle develops the thesis about modern generations. As the author states, the book is directed mainly to parents and teachers in order them to become acquainted with the characteristics of youngsters and to know how to raise and educate them. At first sight the topic is not connected to postmodernism and security but, as we are going to see further, there is a significant difference in the way various generations think and accept the world. This means that when they take the power in their hands at state and world level, they would take decisions and would act just according their established view of life.

Generations are groups of people, who are born and raised within the same period of time and have, if not identical, then close views and view of life, common culture and value system. The main factors that shape each generation are the cultural-social environment, where they form as personalities and the technologies that accompany their growing. It might be said that technologies start playing significant role in the forming of the new generations during the last century.

It is well known that in times of social cataclysms, of accelerated technological development or of mass migration processes the difference between generations sharply grow and affect their essential characteristics - sometimes radically change the way of life, the value dominants, their evaluation of the past and future. As a result, generation waves shorten significantly, and they come each 10-15 years instead the standard 20-25 years. Children of various generations, particularly in the listed conditions, differ from each other significantly.

Representatives of the following generations live in the world to date: the so called generation of builders born from 1930 to 1945; the baby boomers - born after the end of the Second World War to about 1965; X the children born from 1965 to 1980; Y - the ones born from 1980 to 1995; Z - the children that were born in the period $1995-2010$ and the Alpha generation of the ones born since 2010 to date.

Of course, this division is relative and depends highly on the place in the world, where the children are born, which defines social, cultural and technological differences within the same generation. If, anyway, we accept the generations division presented by McCrindle, to date the representatives of the $\mathrm{Y}$ generation have already entered social and public life and even have representatives of theirs in the authorities' structures at regional and national level. For comparison, the newly elected president of France - Emmanuel Macron is born in 1977. The $Z$ generation is at the entrance of higher education, and the Alpha generation - of school.

The $X$ generation met and "conducted" to a high degree the digital revolution. The $Y$ generation grew in the course of it, and the $Z$ generation is practically born in a "new" digital world.

According to the factor degree of use of information technologies, the following four categories of people outline:

Strangers to digital. These are the generations of Elders and Builders. A characteristic of theirs is that they 
are complete predecessors of technologies. Internet, podcast, on-line games, social networks are completely strange terms to them;

Digital Emigrants - the Baby boom generation. They have matured without digital technologies. A part of them take advantage of new technologies successfully, and the rest accept them reluctantly;

Adapting themselves to digital - the $\mathrm{X}$ generation. Digital technologies start appearing (in large-scale) in their teen years. They eagerly embrace the new technologies;

Digital natives $-Y, Z$ and Alpha generations. They live entirely dipped in the digital technologies.

We will review in short the major characteristics of the basic generations that perform more essential role in public life to date.

Baby boomers generation: Born and grown after the end of the Second World War, in the period of sharp confrontation between both, existing then, social systems - the Cold War. However, the period is comparatively peaceful and saturated, especially in the West, with movements and fights for freedom, equality and democracy. The media that shaped their mind are the newspapers (written word) and the radio. This is time of powerful ideological treatment of public consciousness. As a whole, baby boomers are responsible people, socially and communally engaged. To date, they are retired or just before retiring and their possibilities to influence significantly social processes are comparatively limited. As mentioned above, they are digital immigrants, although they have actively participated in the conduction of information revolution. New technologies are strange to them and comparatively small part of them works successfully with modern technical and information tools.

The $X$ generation: They are born and grown in the $70-80^{\mathrm{s}}$ of the $20^{\text {the }}$ century, a period distinguished for peaceful existing together, the start of disarmament processes and relative resumption of the connections on both sides of the "Iron Curtain”. Television is the main media that formed them as personalities. Information from all over the world started reaching them despite ideological treatment and censorship, through it. The processes of globalization come into existence comparatively slowly. They are known as "the children with key around the neck" - raise by busy with work and social activities parents, left to define their daily life and priorities themselves. This logically forms them as individualists and people, capable of taking decisions and respectively of bearing the responsibility for them. To date, they comprise the main part of labour force and authority structures worldwide. Regarding technologies, they are in the base of all technological revolutions conducted in the recent years and, as we mentioned above, accept novelties readily and take advantage at almost full value of their possibilities.

The $Y$ generation: They are born and grown in the boom of computers, which turn to be their major toy. Internet appeared in the period of their adolescence; still it is new technology for them. Democracy bloom is the social environment that formed their personalities - the period of the Berlin wall fall, of world opening and of a lot of freedom. These gave them many choices and one of their important characteristics is that they have the right of choice as unabolished datum. It might be said this is the first generation of postmodern society. The world is really "one big village" for them.

The $\mathrm{Y}$ generation children are raised by the late baby boomers and the early $\mathrm{X}$ - parents that are excessively caring, controlling and imposing their views. These form them as people, who follow rules but are dependable on the others approval. Therefore, they are highly team-oriented but not in the positive meaning of the term. There is rather indecisiveness and fear to take personal responsibility while taking whatever decisions about them and that is why they need team for distributing the responsibility. They manage difficultly with individual assignments, not because of lack of knowledge but because of fearing to take individual responsibility.

Another characteristic feature of this generation, originating mainly from the technological environment of their growing up is the speed and multichannel perception of information. They are capable of watching video, listening to sound and perceiving text information at the same time through and from various channels and of various natures. Modern televisions take advantage of that feature and broadcast various information at the same time, mainly in the news emissions. Actually, the Ys „scan” information flows without entering into the contents. They pay a little bit more attention to what draws their attention but as a whole, perception stays at shallow level. All this leads to forming non-linear, visual thinking in them.

They are quite pragmatic, strongly oriented towards growing in the career. On the other hand, they are highly dependable on entertainment and perceive work and career only from the point of view of ensuring means for more and more quality entertainment. Here are the roots of the fact that they do not tend to conduct any activities outside their direct obligations and working hours as well as activities not corresponding to their personal goals and ambitions. 
One, according to me, among the most important characteristics of this generation is the lack of authorities. As McCrindle says, with them a process of knowledge flowing from the younger to the older generations is for the first time observed in human history. As far as they are considerably better acquainted with new technologies, cases when they are made to teach representatives of previous generations and even their parents and teachers to work with them are not exclusion. This naturally leads to lack of respect towards "the wise elderly". On the other hand, a principle of theirs is "Google knows everything", which leads to not understanding the requirement to fill their heads with large, complicated and "unnecessary" knowledge. They rely on continuous "connectivity" to the net and on the possibility to derive necessary information from it. This, at its turn, becomes reason for nobody to be able to impress them with erudition, culture and knowledge.

Only in some 5-10 years, this generation's representatives would comprise the main part of the labour force worldwide. Their representatives would occupy key positions in all authority structures at all levels.

The $Z$ generation: As McCrindle says, if we square all features of the $Y$ generation, we will get a vague notion of the $Z$ generation's characteristics. I will not go into details about them, because, as I mentioned above, to date these children are at the entrance of higher education.

Alpha generation: Here I would only afford to quote a colleague and friend of mine, who characterizes them by two words - „homo tabletus".

Differences between generations are objective reality that affects social and political processes throughout the world. Perhaps it is suitable here to mention an interpretation of one of the Old Testament's parables, namely - why Moses, taking Judaic people out of the slavery in Egypt, walked around the desert for 40 years before taking it to the Promised Land? The answer, although rude is very demonstrative - in order the generation that remembers slavery to disappear and the new Judaic community to start living without that psychological, emotional and social burden.

The following basic conclusion can be derived from the written up to here: Postmodern society appears to be transitional process for the society passing towards a new social system. As far as practically, we are in the beginning of the process, the characteristics of new cannot be defined and clearly outlined. Most probably the leading element of the new social relations would be based on technologies and scientific progress. The main characteristics for these processes are lack of stationariness, chaotic state and turmoil social processes and events as well as vibration around the main axes, i.e. staggering to unclear new ideas followed by returning back to the old and traditional (Slatinski, 2010a, Slatinski, 2004a).

\section{CONCLUSION}

Postmodern society possesses all characteristics of a transitional process, typical for complex systems going from one status to another. Historical checkups show that such processes are characterized by long duration and as far as to date we are practically in its beginning, the main characteristics of the coming new still cannot be outlined. However, obviously, not only technologies change but also the entire structure of society as well as the way of thinking of people, especially the one of the people of the new generations. This, quite logically and naturally, leads to the feeling of security abating in each single individual as well as in communities and in society as a whole. Thus, the scientific community interest towards studying that paradigm raises, but also the interest of "ordinary" people as far as the practical aspects of theses studies concern their everyday life and existence.

More and more, the world cannot be reviewed as multitude of states and regions that exist separately. Global problems require global solutions. This stimulates researchers to pay more attention to the greaterscale levels of security - "The security of a Community of states" and "Security of the World". There are really gaps and opportunities for studies and analysis in this direction.

\section{REFERENCE LIST}

https://ru.wikipedia.org/wiki/\%D0\%9F\%D0\%BE\%D1\%81\%D1\%82\%D0\%BC\%D0\%BE\%D0\%B4\%D0\%B5\%D 1\%80\%D0\%BD\%D0\%B8\%D0\%B7\%D0\%BC, 03.006.2017, (2017a).

https://bg.wikipedia.org/wiki/\%D0\%A1\%D0\%B8\%D0\%B3\%D1\%83\%D1\%80\%D0\%BD\%D0\%BE\%D1\%81\% D1\%82, 03.06.2017, (2017b).

Slatinski, N. (2014a). Sigurnostta - zhivotat na mrezhata, Voenno izdatelstvo, Sofiya, 2014 (Слатински, Н. 
Сигурността - животът на мрежата, Военно издателство, София, 2014).

http://www.librev.com/index.php/prospects-world-publisher/77-2009-06-17-08-28-18, 05.06.2017, (2017c).

https://bg.wikipedia.org/wiki/\%D0\%93\%D0\%BB\%D0\%BE\%D0\%B1\%D0\%B0\%D0\%BB\%D0\%B8\%D0\%B7\% D0\%B0\%D1\%86\%D0\%B8\%D1\%8F, 05.06.2017, (2017d).

https://bg.wikipedia.org/wiki/\%D0\%9B\%D0\%B5\%D0\%B3\%D0\%B8\%D1\%82\%D0\%B8\%D0\%BC\%D0\%BD\% D0\%BE\%D1\%81\%D1\%82, 05.06.2017, (2017e).

https://ru.wikipedia.org/wiki/\%D0\%A0\%D0\%B5\%D0\%B2\%D0\%BE\%D0\%BB\%D1\%8E\%D1\%86\%D0\%B8\%D $1 \% 8 \mathrm{~F}, 06.06 .2017$, (2017f).

Bauman, Z., (2003a). City of Fears, City of Hopes. London: Goldsmith's College, 2003.

Liotar, Zh. (1996a). Postmodernata situatsiya. Izlozhenie za sastoyanieto na savremennoto znanie, Sofiya, Nauka i izkustvo,1996 (Лиотар Ж., Постмодерната ситуация. Изложение за състоянието на съвременното знание, София, Наука и изкуство,1996).

Bauman, Z. (2003b). Obshtnostta - tarsene na bezopasnost v nesigurniya svyat, LIK, 2003 (Бауман, 3. Общността - търсене на безопасност в несигурния свят, ЛИК, 2003).

McCrindle, M. (2009a). The ABC of XYZ: Understanding the Global Generations, University of New South Wales, Sidney, 2009.

Slatinski, N. (2010a). Pette niva na sigurnost, Sofiya, Voenno izdatelstvo, 2010 (Слатински, Н. Петте нива на сигурност, София, Военно издателство, 2010).

Slatinski, N. (2004a). Natsionalnata sigurnost - Aspekti, Analizi, Alternativi, S. Balgarska knizhnitsa, 2004 (Слатински Н., Националната сигурност - Аспекти, Анализи, Алтернативи, С. Българска книжница, 2004). 